\title{
Spo0A represses transcription of the cry toxin genes in Bacillus thuringiensis
}

\author{
Sandrine Poncet, ${ }^{1,2}$ Etienne Dervyn, ${ }^{1}$ André Klier ${ }^{2}$ and Georges Rapoport ${ }^{2}$
}

Author for correspondence: Sandrine Poncet. Tel: +331346525 09. Fax: +33134652521. e-mail: sponcet@biotec.jouy.inra.fr

1 Unité de Génétique Microbienne, Institut National de la Recherche Agronomique, Domaine de Vilvert, 78352 Jouy en Josas Cedex, France

2 Unité de Biochimie Microbienne, Institut Pasteur, URA 1300 du Centre National de la Recherche Scientifique, 25 rue du Docteur Roux, 75724 Paris Cedex 15, France

\begin{abstract}
The DNA regions upstream from the genes encoding polypeptides of Bacillus thuringiensis subsp. israelensis larvicidal crystals (cry4A, cry4B, cry11A) contain sequences with similarities to the SpO0A box of Bacillus subtilis (or ' $O A$ ' box) and the promoter recognized by the $\sigma^{H}$-associated RNA polymerase of $B$. subtilis. Expression of cry-lacZ transcriptional fusions was analysed in various $B$. thuringiensis genetic backgrounds. The early transcription of the toxin genes was not sporulation-dependent, whereas the late-stage expression at $t_{4-6}$ was $\sigma^{\mathrm{E}}$-dependent. Primer extension analysis confirmed that the cry4and cry11-type toxin genes were weakly transcribed during the transition phase; expression analysis of a cry11A'-lacz transcriptional fusion in B. subtilis sporulation mutants confirmed the involvement of the $\sigma^{H}$-RNA polymerase. Primer extension analysis showed that in $B$. thuringiensis subsp. israelensis, the cry $4 A$ and cry11A gene transcription observed at the end of the growth stage was turned off at the beginning of the sporulation phase. The DNA region located upstream from the cry11A gene promoter including the putative ' $O A$ ' box was deleted. This led to a derepression of the expression of the cry11A operon. These results suggest that the cry4A, cry4B and cry11A toxin genes of $B$. thuringiensis subsp. israelensis are transcribed during the transition phase by the RNA polymerase associated with the $\sigma^{\mathrm{H}}$ factor and are subject to Spo0A repression.
\end{abstract}

Keywords: Bacillus thuringiensis, cry toxin genes, Spo0A, transcription

\section{INTRODUCTION}

Bacillus thuringiensis subsp. israelensis produces complex composite inclusions highly toxic to mosquito and blackfly larvae. The larvicidal specificity of each of the four major crystal components (Cry4A, Cry4B, Cry11A and $\mathrm{Cyt} 1 \mathrm{~A})$ has been characterized. The high toxicity of the inclusions is due in part to synergy between these components (Delécluse et al., 1993; Poncet et al., 1995a). The corresponding genes have been cloned and sequenced from a $72 \mathrm{MDa}$ resident plasmid. Each of these four genes is expressed during the sporulation phase (for a review, see Porter et al., 1993).

In Bacillus subtilis, two transcriptional regulators, $\mathrm{Spo} 0 \mathrm{H}$ (or $\sigma^{\mathrm{H}}$ factor) and $\mathrm{Spo0A}$, are required for the onset of sporulation. $\sigma^{\mathrm{H}}$ is involved in the initiation of the sporulation process in $B$. subtilis, but its precise role has not been yet defined. However, it is known to be involved in post-exponential phase gene transcription (for a review, see Haldenwang, 1995). The spo0A gene is transcribed from two promoters recognized by the RNA polymerase associated with $\sigma^{\mathrm{A}}$ and $\sigma^{\mathrm{H}}$. The regulatory protein Spo0A plays a key role in the initiation of sporulation (Baldus et al., 1994). The phosphorylated form interacts with its DNA target ( $5^{\prime}$ TGTCGAA $3^{\prime}$ ) and thereby represses one set of genes and activates other sporulation-specific genes. After the start of sporulation, the activation of a series of sigma factors, which bind to the core RNA polymerase, allows a timeand compartment-specific regulation of sporulation genes (for reviews, see Haldenwang, 1995; Baldus et al., 1994; Errington, 1993).

The temporal and compartmental gene regulation during the sporulation process in $B$. thuringiensis is very similar to that in B. subtilis, and the Spo0A proteins of $B$. thuringiensis and $B$. subtilis are homologous (Lereclus et al., 1994). Moreover, genes for two sporulation sigma factors have been isolated and sequenced from $B$. thuringiensis: the $\sigma^{35}$ and $\sigma^{28}$ factors [homologous to the mother-cell-specific $\sigma^{\mathrm{E}}$ and $\sigma^{\mathrm{K}}$ factors of $B$. subtilis, 
respectively (Adams et al., 1991)]. More recently, a gene encoding a SpoOF-like protein has been characterized in B. thuringiensis (Malvar \& Baum, 1994).

Most known crystal protein genes of $B$. thuringiensis are under the control of sporulation-specific sigma factors. In B. thuringiensis, the $c r y 1 A a$ gene is transcribed during the sporulation phase from two sporulation-specific promoters (Wong et al., 1983; Brown \& Whiteley, 1988, 1990). In B. thuringiensis subsp. israelensis, the cry $4 A$, $c r y 4 B, c r y 11 A$ and $c y t 1 A$ genes are transcribed during mid-sporulation from promoters recognized by the $\sigma^{35}$-RNA polymerase; moreover, transcription of the cyt $1 \mathrm{~A}$ and $c r y 11 \mathrm{~A}$ genes continues into late-sporulation from promoters recognized by the $\sigma^{28}-$ RNA polymerase ( Waalwijk et al., 1985; Ward \& Ellar, 1986; Yoshisue et al., 1993, 1994; Dervyn et al., 1995).

We compared DNA regions located upstream from each of the toxin genes to identify putative conserved sequences possibly involved in the regulation of the four toxin genes in B. thuringiensis subsp. israelensis. We found sequences similar to the ' $0 \mathrm{~A}$ ' box and the consensus -10 and -35 boxes recognized by the $\sigma^{\mathrm{H}}-\mathrm{RNA}$ polymerase in $B$. subtilis. Thus, $B$. thuringiensis subsp. israelensis toxin genes may also be transcribed early during sporulation. Expression studies and deletion analysis were performed to identify the role of these sequences in toxin gene regulation. cry $4 A, c r y 4 B$ and $c r y 11 A$ were weakly transcribed during the transition phase, probably under the control of the RNA polymerase associated with a $\sigma^{\mathrm{H}}$-like factor, and the cry $11 \mathrm{~A}$ operon was negatively regulated by Spo0A.

\section{METHODS}

Bacterial strains and media. Total RNA was extracted from $B$. thuringiensis subsp. israelensis strain 4Q2-72, which harbours the $72 \mathrm{MDa}$ resident plasmid encoding all the crystal proteins. The acrystalliferous isogenic strain 4Q2-81, $B$. thuringiensis strains 407-0A (spoOA::kan) (Lereclus et al.,
1994) and B. thuringiensis 407-sigE (sigE: kan) (Bravo et al., 1996) were used as recipient strains for transformation experiments; they are derived from strain 407 (serotype 1). $B$. thuringiensis subsp. israelensis strains 4Q2-72 and 4Q2-81 were kindly provided by D. H. Dean, Ohio State University, Columbus, OH, USA. B. thuringiensis strains were transformed by electroporation (Lereclus et al., 1989) and transformants selected on Luria Broth (LB) plates containing erythromycin $\left(10 \mu \mathrm{g} \mathrm{ml}^{-1}\right)$.

Escherichia coli $\mathrm{K}-12$ strain TG1 $[\Delta$ (lac-proAB) supE thi hds D5 $\mathrm{F}^{\prime}\left(\right.$ tra $D 36$ pro $A^{+}$proB $^{+}$lacl $^{\mathrm{q}}$ lacZ $\left.\Delta \mathrm{M} 15\right)$ ] was used for plasmid construction. Transformants were selected on LB plates supplemented with ampicillin $\left(100 \mu \mathrm{g} \mathrm{ml}^{-1}\right)$.

B. subtilis strains FBT17, FBT20 and FBT21 were constructed to investigate the role of $\sigma^{\mathrm{H}}$ and AbrB in the regulation of the cry11A operon (Table 1). The spoOH strain IS233 (Weir et al., 1984) was transformed with chromosomal DNA from strain FBT11, giving strain FBT17. As the $a b r B$ strain JH12586 (Perego et al., 1988) is chloramphenicol-resistant, chromosomal cry11 $A^{\prime}-$ lac $Z$ cat DNA could not be used for studying the role of AbrB. Plasmid pBT11 was therefore constructed as follows. Plasmid pBT10 (Dervyn et al., 1995) was digested with EcoRI and SacI. The resulting DNA fragment was inserted between the EcoRI and SacI sites in pAC7 (Weinrauch et al., 1991) giving pBT11, which carries a cry11 $A^{\prime}-l a c Z$ kan DNA fragment. pBT11 was used to transform B. subtilis strain 168 , and strain FBT20 was obtained through integration of the cry11 $A^{\prime}-$ lacZ kan DNA fragment at the amyE locus by homologous recombination. Chromosomal DNA from strain FBT20 was used to transform strain JH12586, giving strain FBT21 (Table 1). Recombinants were selected on LB plates supplemented with erythromycin $\left(0 \cdot 3 \mu \mathrm{g} \mathrm{ml}^{-1}\right)$, kanamycin $\left(10 \mu \mathrm{g} \mathrm{ml}^{-1}\right)$ or chloramphenicol $\left(10 \mu \mathrm{g} \mathrm{ml}^{-1}\right)$.

B. thuringiensis strains were grown at $37^{\circ} \mathrm{C}$ in LB medium or at $30^{\circ} \mathrm{C}$ in HCT medium (Lecadet et al., 1980). E. coli was grown at $37^{\circ} \mathrm{C}$ in LB medium. B. subtilis was grown at $37^{\circ} \mathrm{C}$ in nutrient broth sporulation medium (SP medium) containing $8 \mathrm{~g}$ nutrient broth (Difco) $\mathrm{l}^{-1}, 1 \mathrm{mM} \mathrm{MgSO}, 13 \mathrm{mM} \mathrm{KCl}$ and $10 \mu \mathrm{M} \mathrm{MnCl}{ }_{2}$; after sterilization, $4.4 \mathrm{mg}$ ferric ammonium citrate $\mathrm{l}^{-1}$, and $\mathrm{CaCl}_{2}$ to $0.5 \mathrm{mM}$ were added.

Plasmids. pHT643, which carries the $p 19$, cry11A and $p 20$ genes, has already been described (Dervyn et al., 1995; see Fig.

Table 1. B. subtilis strains used in this study and expression of cry11 $A^{\prime}-l a c Z$ transcriptional fusion at $t_{-1.5}$

\begin{tabular}{|c|c|c|c|}
\hline Strain & Genotype & Source or reference & $\begin{array}{c}\beta \text {-Galactosidase } \\
\text { activity }\end{array}$ \\
\hline 168 & $\operatorname{trpC} 2$ & Laboratory stock & ND \\
\hline JH12586 & $\operatorname{trp} C 2$ phe A1 abrB::cat & Perego et al. (1988) & ND \\
\hline IS233 & $\operatorname{trpC} 2$ pheA1 $\Delta s i g H$ & Weir et al. (1984) & ND \\
\hline FBT11 & $\operatorname{trp} C 2$ amyE::(cry11 $A^{\prime}-$ lac $Z$ cat $)$ & Dervyn et al. (1995) & $28(26-31)$ \\
\hline FBT12 & $\operatorname{trp} C 2$ amyE::(cry11 $A^{\prime}-l a c Z$ cat $)$ spo0A:: kan & Dervyn et al. (1995) & $5(4-6)$ \\
\hline FBT14 & $\operatorname{trp} C 2$ amyE::(cry11A'-lacZ cat $) \Delta s i g E$ & Dervyn et al. (1995) & $32(29-35)$ \\
\hline FBT17 & $\operatorname{trp} \mathrm{C} 2$ pheA1 amyE::(cry11A'-lacZ cat $) \Delta s i g H$ & This work & $4(3-6)$ \\
\hline FBT20 & $\operatorname{trpC2}$ amyE::(cry11A'-lacZ kan $)$ & This work & ND \\
\hline FBT21 & trpC2 pheA1 amyE ::(cry11 $A^{\prime}-$ lacZ kan) abrB::cat & This work & $90(85-95)$ \\
\hline
\end{tabular}

ND, Not determined.

*Values shown are the means of four to eight independent experiments and are expressed in Miller units (mg protein) ${ }^{-1}$. Numbers in parentheses are $95 \%$ confidence limits as determined by probit analysis. 
(a)

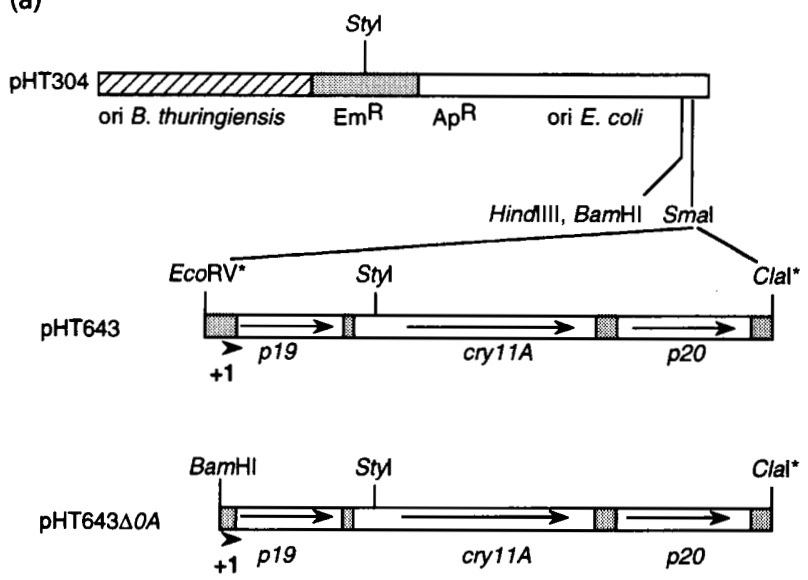

(b)

\begin{tabular}{|c|c|c|c|c|}
\hline $\begin{array}{l}\text { EcoRV } \\
\text { GATATCGCCA }\end{array}$ & AAATGAAATC & TAATTTAAGA & GTATGTATTT & TCATAAAATA \\
\hline GTTTCGTATG & AGATTTTATT & ATTTTGAAAC & AATATTTCTT & ATTTTTATAT \\
\hline ACATAAGTAC & CATTTATTCA & GAGAAGACTT & ATCCATCGGA & AGATTTTTCA \\
\hline AATGGCTATA & TGATATAGTA & TCTTGTTTTT & 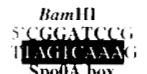 & $\begin{array}{l}\text { ATACATTTTT } \\
\text { ATACATTTTT }\end{array}$ \\
\hline $\begin{array}{l}\text { GTTTATACAT } \\
\text { GTTAATACAT }\end{array}$ & $\begin{array}{l}\text { GC 3' } \\
\frac{\text { GCATCGTTTT }}{-35}\end{array}$ & TATACAAGTA & $\frac{\text { ACATATATTT }}{-10}$ & $\underset{+1}{\text { GTTATGTAAC }}$ \\
\hline ATAG & TGAAATTGGT & ACTAAATTTT & TAAGAAAGAT & ATTTTGAAAT \\
\hline TTA & AAGTTTTTT & AAAATTGCAT & AGAAGGGAGA & $\mathrm{A}$ \\
\hline
\end{tabular}

ATG
Met
start PI

start P19

Fig. 1. Construction of plasmids for the analysis of cry $11 \mathrm{~A}$ expression. (a) Simplified restriction maps of the recombinant plasmids containing all or part of the cry11A operon from which the ' $O A$ ' box has been deleted ( $\mathrm{pHT} 643$ and $\mathrm{pHT} 643 \triangle 0 \mathrm{~A}$, respectively). The arrows indicate the position and direction of transcription of the p19, cry11A and p20 genes. Asterisks indicate that restriction sites have been lost. (b) Nucleotide sequence of the promoter region from the cry11A operon. The ribosome-binding site (RBS) is underlined and -35 and -10 consensus boxes of the PI promoter are in bold letters and underlined. The transcriptional start point $(+1)$ and putative ' $O A$ ' box are also indicated. The sequence of the primer used for deletion of the 'OA' box, creating a BamHI site, is given above the DNA sequence.

1a). pHT643 $\triangle 0 A$ was obtained as follows. A DNA fragment was amplified by PCR to create a $B a m H I$ restriction site upstream from the -35 box of the cry11A gene PI transcriptional start point (corresponding primer $5^{\prime}$ CGGATCCGATACATTTTTGTTTATACATGC 3'; see Fig. 1b). The second primer ( $5^{\prime}$ GAAAATAACCCTTGGCTG $3^{\prime}$ ) is complementary to nucleotides overlapping the StyI site in the coding sequence of $c r y 11 \mathrm{~A}$. pEG217 was used as the template (Donovan et al., 1988). The $1191 \mathrm{bp} \mathrm{PCR} \mathrm{product} \mathrm{was}$ digested with Bam HI and StyI, purified and ligated to pHT643 digested with BamHI and StyI. The result was pHT643 $\triangle 0 A$ which carries a $184 \mathrm{bp}$ deletion in front of the PI promoter -35 box (see Fig. 1a).

pHT691 (containing the cry4 $A^{\prime}-$ lacZ fusion), pHT692 (containing the $c r y 4 B^{\prime}--l a c Z$ fusion) (Delécluse et al., 1993) and pHT693 (containing the $c r y 11 A^{\prime}-$ lacZ fusion) (Dervyn et al., 1995) have already been described.

pHT694, carrying a transcriptional fusion between the cry $11 \mathrm{~A}$ operon promoter deleted for the putative ' $0 \mathrm{~A}$ ' box and the lacZ gene, was obtained as follows. pHT643 $\triangle 0 A$ was hydrolysed with StyI, blunt-ended with Klenow fragment, then digested with HindIII. The resulting DNA fragment carrying the modified cry $11 \mathrm{~A}$ promoter region was inserted into pHT304-18Z (Agaisse \& Lereclus, 1994) cut with BamHI, blunt-ended with Klenow fragment and restricted with HindIII.

DNA manipulation. Plasmid DNA was extracted from $E$. coli by the standard alkaline lysis procedure (Birnboim \& Doly, 1979). Restriction enzymes and Klenow fragment were used as recommended by the manufacturers (Amersham and Boehringer Mannheim). Chromosomal DNA was extracted from B. subtilis as previously described (Msadek et al., 1990).

PCRs were carried out by using the thermostable Thermus aquaticus DNA polymerase as recommended by the supplier (Amersham), using oligonucleotides synthesized by Genset.

The GCG program (Genetics Computer Group, University of Wisconsin, Madison, WI, USA) was used for computer analysis.

RNA extraction and primer extension. Total RNA was extracted from $B$. thuringiensis cells grown in HCT medium as previously described (Glatron \& Rapoport, 1972). Elongation of the radioactive DNA primers and analysis of the products were performed as previously described (Calogero et al., 1994). DNA sequences were determined by the dideoxy chain-termination method (Sanger et al., 1977) with a Sequenase version $2 \cdot 0 \mathrm{kit}$ (US Biochemical) and $\left[\alpha^{35} \mathrm{~S}\right] \mathrm{dATP} \alpha \mathrm{S}$ (15 TBq; Amersham).

The specific primer used to detect the $c r y 4 A$ transcript was 5' TGACCCTTATGCATTTATCCTCTCC 3' (complementary to nucleotides +56 to +80 of the cry $4 A$ transcript (Yoshisue et al., 1993); the primer used to detect the cry4B transcript was $5^{\prime}$ CATACAGTCTCTGGACAATTTACAGAAATC 3' (corresponding to primer 2, Yoshisue et al., 1994); the probe used to detect the cry $11 A$-specific transcript has been described previously (Dervyn et al., 1995).

ק-Galactosidase assays. B. subtilis strains containing the cry $11 A^{\prime}-$ lac $Z$ fusion and $B$. thuringiensis strains containing either the $c r y 11 A^{\prime}-, \Delta 0 A c r y 11 A^{\prime}-$, cry $4 A^{\prime}-$ or $c r y 4 B^{\prime}-l a c Z$ fusions were grown in SP or HCT medium, respectively, supplemented with appropriate antibiotics. $\beta$-Galactosidase was assayed as follows. $B$. thuringiensis cultures were concentrated twofold in $Z$ buffer (Miller, 1972) and disrupted by ultrasonic disintegration (for $1 \mathrm{~min}$ with a Branson sonifier at $30 \%$ duty cycle). Cell debris was eliminated by centrifugation at $7000 \mathrm{~g}$ for $10 \mathrm{~min}$, and the $\beta$-galactosidase activity in the supernatant was determined as described by Miller (1972). $B$. subtilis cultures were tested for $\beta$-galactosidase activity as previously described (Msadek et al., 1990).

\section{RESULTS}

\section{DNA sequence comparison}

The DNA sequences of the $c r y 4 A, c r y 4 B$ and $c r y 11 A$ promoter regions were compared. No extensive similarities were found. However, local DNA sequence 
(a)

\begin{tabular}{|c|c|c|}
\hline Consensus 'OA' box from $B$. subtilis & TCITCCAAA & \\
\hline $\begin{array}{l}\text { cry } 4 A \\
\text { cry } 4 B \\
\text { cry11A }\end{array}$ & $\begin{array}{l}\text { TGTCAAA } \\
\text { GGTCAAA } \\
\text { AGTCA A }\end{array}$ & $\begin{array}{l}-76 \text { to }-70 \\
-50 \text { to }-45 \\
-62 \text { to }-56\end{array}$ \\
\hline B. thuringiensis spoOA gene & TGTCGAA & +7 to +13 \\
\hline
\end{tabular}

(b)

$\sigma^{E}$ consensus promoter from B. subtilis

cry $4 A$

cry4B

cry11A

$\sigma^{H}$ consensus promoter from $B$. subtilis

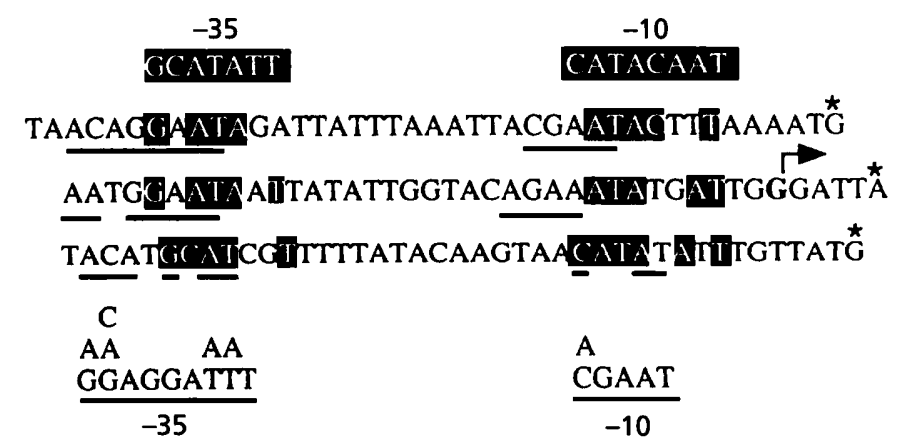

Fig. 2. Sequence comparison of putative ' $O A$ ' boxes from $B$. thuringiensis with the consensus ' $O A$ ' box from $B$. subtilis (a) and alignment of DNA sequences matching consensus promoters recognized by either $\sigma^{\mathrm{E}}$ or $\sigma^{\mathrm{H}}$ in $B$. subtilis (b). (a) Sequence comparison of putative Spo0A-binding boxes of $B$. thuringiensis subsp. israelensis cry $4 A$, cry $4 B$ and cry $11 A$ toxin genes with the consensus $B$. subtilis ' $O A^{\prime}$ ' box. Identical nucleotides are boxed. The position of each box is given with respect to the nearest corresponding start point. (b) Alignment of nucleotide sequences from promoter regions of the cry4-type and cry11A genes from $B$. thuringiensis subsp. israelensis. The nucleotides which match the consensus sequence of the $\sigma^{E}$ recognition site of $B$. subtilis are boxed. The underlined nucleotides correspond to those which match the consensus promoter recognized by $\sigma^{H}$ in $B$. subtilis. The asterisks designate the nucleotides corresponding to the $5^{\prime}$ end of the mRNA. For cry $4 A$ and $c r y 11 A$, the same transcriptional start points were detected at $t_{-2}\left(\sigma^{\mathrm{H}}\right.$-dependent, see Fig. 3a, $c$, lanes $t_{-2}$ ) and in mid-sporulation ( $\sigma^{\mathrm{E}}$-dependent, this work and data not shown; Yoshisue et al., 1995; Dervyn et al., 1995). For cry4B, the transcriptional start point detected in the 407-0A and the 4Q2-72 strains (this work, bold letter with arrow) was five nucleotides upstream from that determined by Yoshisue et al. (1994) in sporulating cells (asterisk).

similarity was found upstream from the -35 and -10 promoter boxes of the three promoter regions. These sequences (Fig. 2a) show significant similarities with the consensus '0A' box of $B$. subtilis (Strauch et al., 1990; for a review, see Errington, 1993) and with the putative Spo0A-binding site downstream from the $\sigma^{\mathrm{A}}$-dependent promoter of the $B$. thuringiensis spo0 A gene (Lereclus et al., 1994). In particular, the highly conserved $G$ and $C$ residues were found (Baldus et al., 1994). A sequence was also found upstream from the $c r y 4 A, c r y 4 B$ and cry $11 A$ genes which matches both the -35 and -10 consensus promoter sites recognized by the RNA polymerase of $B$. subtilis associated with the $\sigma^{\mathrm{H}}$ factor (Fig. 2b).

\section{Negative regulation of the toxin genes at the onset of the sporulation process}

The $\sigma^{\mathrm{H}}$-associated RNA polymerase transcribes genes during the transition phase in $B$. subtilis; the regulatory protein Spo0A interacts with both $\sigma^{\mathrm{A}}$ - and $\sigma^{\mathrm{H}}$-dependent promoters, acting as either a negative or a positive effector of gene expression (Baldus et al., 1994, 1995). Primer extension experiments were performed using total RNA extracted from $B$. thuringiensis with primers specific for $c r y 4 A$ or $c r y 4 B$ and a probe specific for cry $11 A$, respectively. The $c r y 4 A$ and $c r y 11 A$ genes were transcribed at the end of the exponential phase (Fig. 3a, c, lanes $t_{-2}$, where $t_{n}$ denotes $n$ hours after the start of sporulation). No vegetative transcription of the $c r y 4 A$ and $c r y 11 A$ genes was detected at the beginning of the sporulation (Fig. 3a, c, lanes $t_{0}$ ). No cry $4 B$ transcript was detected at $t_{-2}$ in wild-type cells (strain 4Q2-72). Primer extension experiments were performed on RNA extracted from 407-0A(pHT692) cells, containing a cry4B'lacZ transcriptional fusion. The cry $4 B^{\prime}-l a c Z$ mRNA was detected in this $s p o 0 A$ background (Fig. 3b, lane $t_{-2}$; the $5^{\prime}$ end of this transcript corresponded to the $5^{\prime}$ end of the $c r y 4 B$ transcript detected at $t_{9}$ in the wild-type strain 4Q2-72 (Fig. 3b, lane $t_{+9}$ ). The failure to detect the cry $4 B$ transcript in the wild-type background may therefore be due to the sensitivity level rather than to the absence of the corresponding transcript in strain 4Q272. Yoshisue et al. (1995) previously showed that in $B$. subtilis cry $4 \mathrm{~A}$ is recognized by $\sigma^{\mathrm{H}}$. By analogy with B. subtilis, $\sigma^{\mathrm{H}}$ may transcribe the $B$. thuringiensis subsp. israelensis cry genes, and Spo0A may repress cry gene transcription through interaction with the putative ' $0 \mathrm{~A}$ ' boxes. The ' $0 \mathrm{~A}$ ' box located upstream from the cry $11 \mathrm{~A}$ operon was therefore investigated. We tested the level of 
(a)

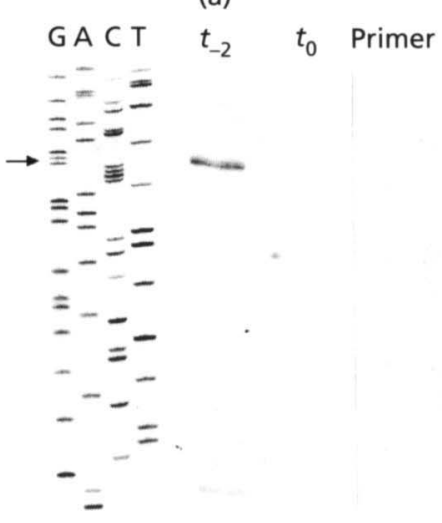

(b)

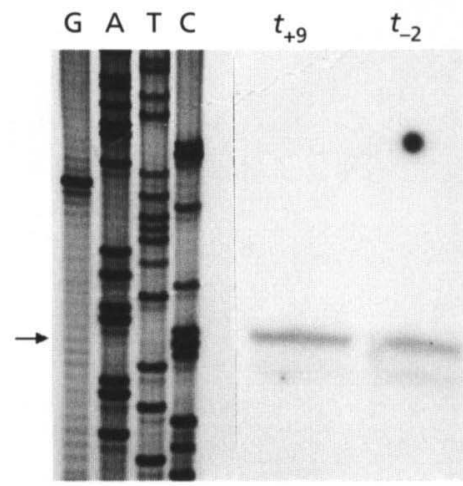

(c)

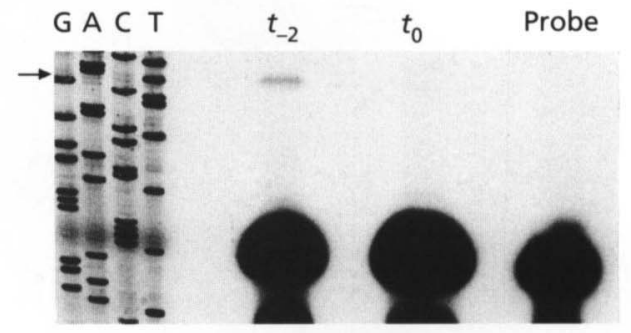

Fig. 3. Reverse transcriptase mapping of the transcriptional start sites of the cry $4 A$ (a), cry $4 B$ (b) and cry $11 A$ (c) genes. $(a, c)$ Total RNA was extracted from B. thuringiensis subsp. israelensis strain 4Q2-72 (harbouring the 72 MDa plasmid encoding all the crystal protein genes). Cells were grown in HCT medium and harvested $2 \mathrm{~h}$ before the beginning of the sporulation phase (lane $t_{-2}$ ) and at the beginning of sporulation (lane $t_{0}$ ) as previously described; (b) total RNA was extracted from strain 407-0A (pHT692) at $t_{-2}$ and from strain $4 Q 2-72$ at $t_{9}$ (lanes $t_{-2}$ and $t_{+9}$, respectively). Extension products are designated by arrows. Lengths of the cry $4 A$ and cry $11 A$ extension products were determined by comparison with the sequence obtained by sequencing the M13mp18 ssDNA; the position of the cry4B mRNA $5^{\prime}$ end is given with respect to the sequence of the corresponding region from pHT692 (containing a cry $4 B^{\prime}-l a c Z$ fusion).

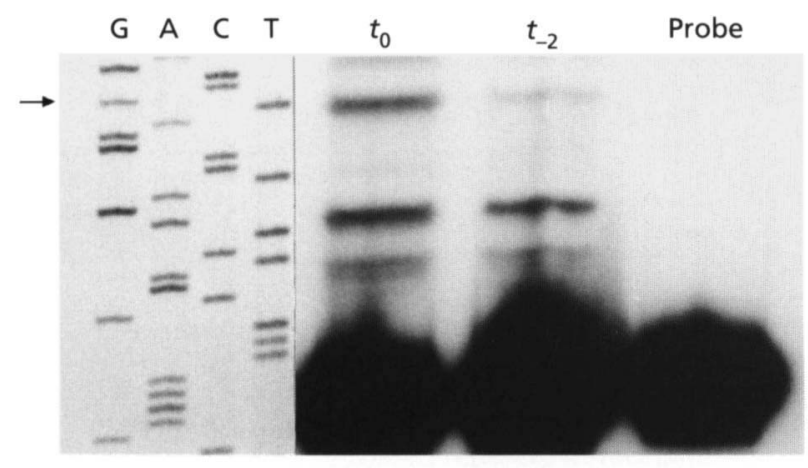

Fig. 4. Mapping of the cry11A gene start site after deletion of the upstream region, including the putative ' $O A$ ' box. Primer extension experiments were performed as described in Fig. 3. The extension product corresponding to the $5^{\prime}$ end of the cry 11 A transcript shown in Fig. 3(c) is shown by an arrow.

expression of transcriptional $c r y^{\prime}-$ lacZ fusions in sporulation mutants of $B$. thuringiensis to characterize the temporal regulation of the toxin genes.

\section{Effect of deletion of the putative Spo0A box on cry11A transcription}

The role of the putative ' $0 \mathrm{~A}$ ' box located upstream from the cry $11 \mathrm{~A}$ gene promoter was tested by deletion analysis. Plasmid pHT643 $\triangle 0 A$ is a derivative of $\mathrm{pHT} 643$ with a $184 \mathrm{bp}$ deletion upstream from the -35 box of the cry $11 A$ PI promoter (Fig. 1). It was introduced by electroporation into the $B$. thuringiensis subsp. israelensis acrystalliferous strain 4Q2-81. Its transcriptional start site PI was active at both $t_{-2}$ and $t_{0}$ (Fig. 4). The $5^{\prime}$ end of the $\Delta 0 A c r y 11 A$ transcript was the same as that identified for the cry $11 \mathrm{~A}$ operon (Fig. 3c, lane $\left.t_{-2}\right)$, although two lower bands were detected, which may correspond to additional promoters or to reverse transcriptase pause sites. Thus the putative ' $0 \mathrm{~A}$ ' box or a sequence in the $184 \mathrm{bp}$ deleted segment is responsible for the $c r y 11 A$ transcriptional repression at the onset of the sporulation process. Similar amounts of Cry11A inclusion were produced in the presence or in the absence [strains 4Q2-81(pHT643) and 4Q2-81(pHT643 $\Delta 0 A)$, respectively] of the putative Spo0A box as assessed by SDS-PAGE (data not shown).

\section{Time course of $\beta$-galactosidase expression in B. thuringiensis}

Plasmids pHT691 (cry4A'-lacZ, Fig. 5a), pHT692 (cry4B'-lacZ, Fig. 5b) and pHT693 (cry11 $A^{\prime}-$ lacZ, Fig. 5c) were introduced into $B$. thuringiensis strains $4 \mathrm{Q} 2-81$, 407-0A and 407-sigE. The strains were cultured in HCT medium at $30^{\circ} \mathrm{C}$; aliquots were harvested at different stages of sporulation and $\beta$-galactosidase activity assayed. No significant $\beta$-galactosidase activity was detected in extracts from strains carrying the plasmid vector alone ( $\mathrm{pHT} 304-18 \mathrm{Z}$ ) (less than 7 Miller units (mg protein $)^{-1}$; data not shown). In the $\mathrm{Spo}^{+}$background (strain 4Q2-81), the cry-type promoters drove synthesis of $\beta$-galactosidase from $t_{4}$ to $t_{5}$; however, small amounts of $\beta$-galactosidase were also detected in early sporulation $\left(t_{-1}\right.$ to $\left.t_{4}\right)$ (Fig. 5a, b, c, open circles). To test whether the early transcription was dependent on the sporulationspecific sigma factors, strains 407-sigE(pHT691), 407sigE(pHT692) and 407-sigE(pHT693) were assayed for $\beta$-galactosidase activity. Late expression was abolished in a sigE background for all the fusions (Fig. 5a, b, c, triangles) but not in a sigK strain (data not shown). Thus, late cry $4 A, c r y 4 B$ and $c r y 11 A$ gene transcription 


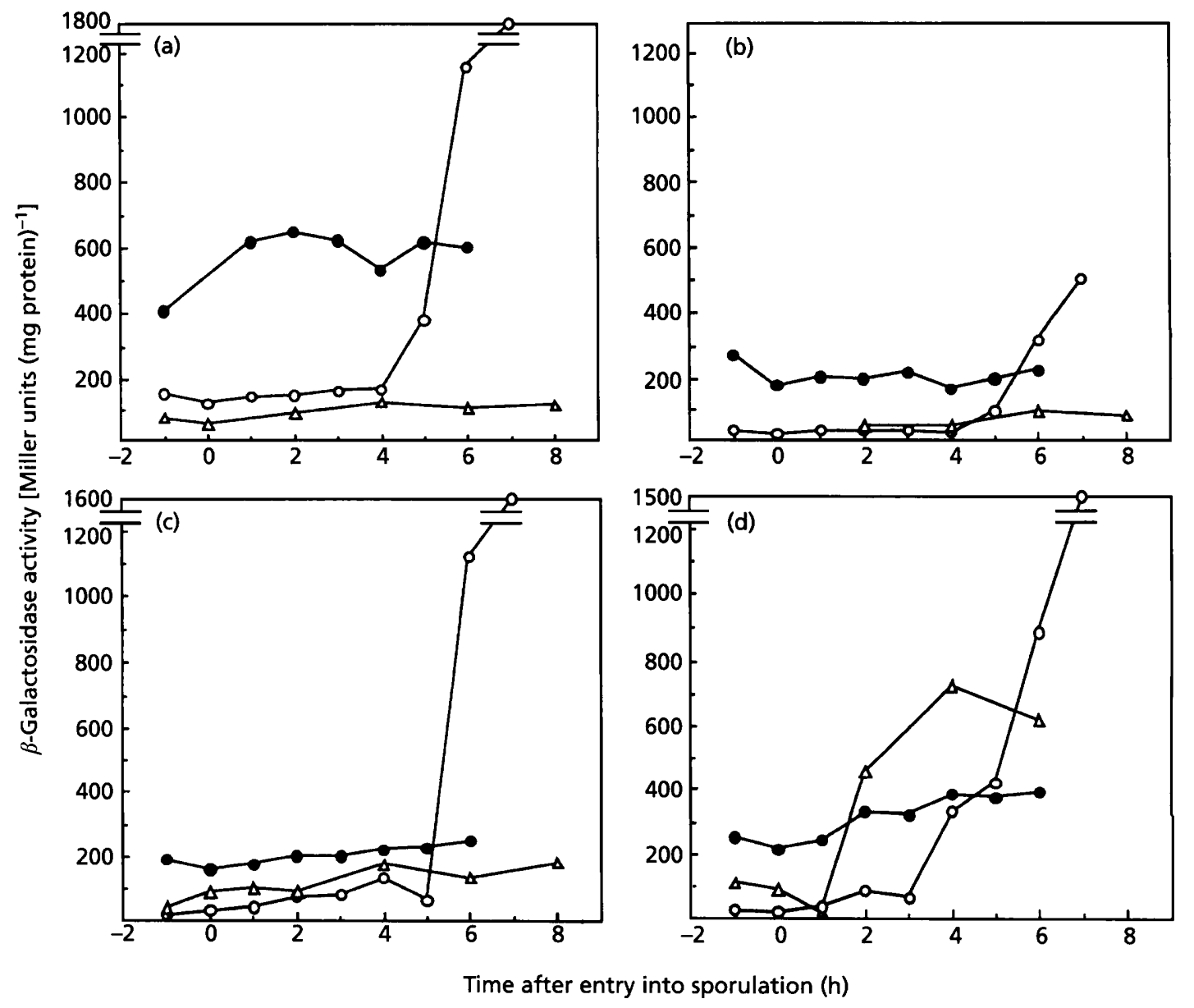

Fig. 5. Time course of cry gene expression in $B$. thuringiensis. Cell extracts from various strains of $B$. thuringiensis

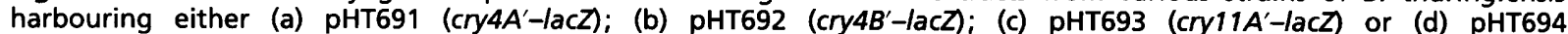
(cry11A $\triangle O A^{\prime}-$ lacZ) were used. $\beta$-Galactosidase specific activity [in Miller units (mg protein) ${ }^{-1}$ ] was determined at various sporulation phases ( $t_{0}$ corresponding to the entry to sporulation) for $B$. thuringiensis strain 4 Q2-81 (Spo+ background, open circles), strain 407-sigE (triangles) and strain 407-0A (spo0A background, closed circles).

was dependent on $\sigma^{\mathrm{E}}$. However, there was $\beta$ galactosidase synthesis, albeit low, from $t_{-1}$ to $t_{4}$ in $\operatorname{sig} E$ strains (Fig. 5a, b, c, triangles), suggesting that the transcriptional activity of the cry $4 A$, cry $4 B$ and $c r y 11 A$ promoters from $t_{-1}$ to $t_{4}$ was not dependent on $\sigma^{\mathrm{E}}$. $\beta$-Galactosidase expression from the $c r y^{\prime}-$ lacZ transcriptional fusions in strain 407-0A (spo0A) between $t_{-1}$ and $t_{4}$ (Fig. 5a, b, c, closed circles) was about threefold higher than in the wild-type strain (Fig. 5a, b, c, open circles). These results suggest that the $B$. thuringiensis subsp. israelensis cry genes may also be controlled by a vegetative- or a transition-phase-specific sigma factor. Sequence analysis suggests the presence of $\sigma^{\mathrm{H}}$-specific promoters overlapping the $\sigma^{\mathrm{E}}$-specific promoters for the cry $4 A$, cry $4 B$ and cry $11 A$ genes (Fig. 2b). Expression studies were performed in $B$. subtilis to demonstrate the $\sigma^{\mathrm{H}}$-dependence of the $\operatorname{cr} 111 \mathrm{~A}$ gene.

\section{Regulation of cry11A expression in B. subtilis}

No spoOH B. thuringiensis strain is currently available. Therefore, to test for a $\sigma^{\mathrm{H}}$-dependent promoter of the cry $11 A$ operon, the $c r y 11 A^{\prime}-l a c Z$ transcriptional fusion was introduced as a single copy at the amyE locus in the chromosome of various sporulation mutants of $B$. subtilis (Table 1). Recombinant cells were cultured in SP medium at $37^{\circ} \mathrm{C}$, and $\beta$-galactosidase activity was assayed at the $t_{-1 \cdot 5}$ stage (Table 1 ). $\beta$-Galactosidase activity in strains bearing the lac $Z$ gene without a promoter at the amyE locus was low [less than 2-3 Miller units (mg protein) ${ }^{-1}$; data not shown]. $\beta$-Galactosidase activities in strains FBT11 (wild-type background) and FBT14 (sigE) were equivalent (see Table 1), evidence that $\sigma^{\mathrm{E}}$ is not involved in the cry $11 \mathrm{~A}$ expression at this stage of sporulation in B. subtilis as in $B$. thuringiensis. In contrast, lac $Z$ expression in strains FBT12 (spo0A background) and FBT17 (sigH) corresponded to the level of activity in control strains bearing the lac $Z$ gene without the cry promoter. These results showed that both SpoOA and $\sigma^{\mathrm{H}}$ are involved in the positive regulation of $c r y 11 A$. In B. subtilis, spoOH is negatively regulated by AbrB (Weir et al., 1991). $\beta$-Galactosidase activity in strain FBT21 $(\Delta a b r B)$ was therefore tested; it was threefold higher than that of the 
wild-type strain. It seems therefore that in B. subtilis cry $11 A$ expression during the transition state is $\sigma^{\mathrm{H}}$ dependent. In B. subtilis, Spo0A positively regulates the expression of $\sigma^{\mathrm{H}}$. Weir et al. (1991) showed that spoOH expression is five- to tenfold reduced in a $B$. subtilis spo0A mutant. This may explain why expression of cry $11 A$ in $B$. subtilis was lower in strain FBT12 (spo0A background, Table 1) than in the wild-type strain.

\section{Role of the putative ' $O A$ ' box in $B$. thuringiensis}

$\beta$-Galactosidase synthesis directed by the $c r y 11 A$ promoter in the presence (pHT693, Fig. 5c) or absence (pHT694, Fig. 5d) of the putative ' 0 A' box was analysed in various $B$. thuringiensis sporulation mutants. The time course of expression of $\beta$-galactosidase in strains 4 Q2-81 and 407-0A, harbouring either pHT693 or pHT694, respectively (Fig. 5c, d) was roughly comparable (open and closed circles, respectively); however, in the $\mathrm{Spo}^{+}$strain, in the absence of the ' $0 \mathrm{~A}$ ' box (Fig. $5 \mathrm{~d}), \beta$-galactosidase synthesis started at $t_{3}$, rather than $t_{5}$ for the wild-type promoter (Fig. 5c). In addition, deletion of the putative ' $O A$ ' box led to a significant derepression at $t_{1}$ in the sigE strain (Fig. $5 \mathrm{~d}$, triangles) compared to the wild-type promoter (Fig. 5c, triangles). These results suggest that the ' $0 \mathrm{~A}$ ' box, or a sequence in the deleted DNA region, is involved in the transcriptional repression of the $c r y 11 A$ operon during entry into sporulation. As cry $11 A$ expression in $B$. thuringiensis and $B$. subtilis spoOA strains is not equal (threefold higher and sixfold lower than in the corresponding $\mathrm{Spo}^{+}$strains, respectively), we cannot exclude the possibility that regulation of the cry $11 \mathrm{~A}$ operon is different in the two bacteria. If Spo0A induces the expression of $\sigma^{\mathrm{H}}$ in B. thuringiensis as in B. subtilis, the absence of Spo0A in B. thuringiensis 407-0A would lead to a lower expression of $\sigma^{\mathrm{H}}$. In B. thuringiensis 407$0 \mathrm{~A}$, the absence of SpoOA may therefore indirectly down-regulate the $\sigma^{\mathrm{H}}$-dependent transcription of cry $11 A$ during the transition phase. Indeed, no obvious induction of the $c r y 11 A^{\prime}-l a c Z$ fusion was observed in a spo0A background (Fig. $5 \mathrm{c}$, closed circles). The Spo0A and $\sigma^{\mathrm{H}}$ regulatory factors are synthesized in the $\operatorname{sig} E$ background. In the presence of the ' $0 \mathrm{~A}$ ' box, Spo0A interacts with its target and may thereby repress the expression of the cry11 $A^{\prime}-l a c Z$ fusion (Fig. $5 \mathrm{c}$, triangles). By contrast, in the absence of the ' $0 \mathrm{~A}$ ' box (cry11A $\triangle 0 A^{\prime}-$ lacZ, Fig. 5d, triangles), the Spo0A regulatory protein would not interact with the cry $11 \mathrm{~A}$ promoter region and the RNA polymerase associated with $\sigma^{\mathrm{H}}$ would transcribe the fusion, leading to the synthesis of $\beta$-galactosidase after $t_{1}$.

\section{DISCUSSION}

In $B$. thuringiensis subsp. israelensis cry $4 A$, cry $4 B$ and cry $11 A$ are believed to be transcribed by the RNA polymerase associated with the sporulation-specific $\sigma^{\mathrm{E}}$ factor at the mid-sporulation stage (for reviews, see Agaisse \& Lereclus, 1995; Baum \& Malvar, 1995). Our findings support this view, since $c r y 4^{\prime}-l a c Z$ and cry $11 A^{\prime}-l a c Z$ transcriptional fusions were not expressed after $t_{5}$ in a $\operatorname{sig} E$ strain of $B$. thuringiensis. However, primer extension analysis and expression studies in sporulation mutants of $B$. thuringiensis showed that cry $4 A$, cry $4 B$ and cry $11 A$ were weakly transcribed during the late exponential phase from a promoter overlapping the $\sigma^{\mathrm{E}}$ consensus sequences. The transcriptional start sites of the cry $4 A$ and $c r y 11 A$ genes have already been determined in sporulating $B$. thuringiensis cells (Yoshisue et al., 1993; Dervyn et al., 1995). The $5^{\prime}$ end of the $c r y 4 B^{\prime}-l a c Z$ mRNA in both spoOA and wild-type backgrounds is located five nucleotides upstream from the cry $4 B$ mRNA $5^{\prime}$ end reported by Yoshisue et al. (1994). The cry11A transcript is present in $B$. thuringiensis cells grown in a sporulation medium at $t_{-2}$ and after $t_{5}$ but is undetectable between $t_{0}$ and $t_{5}$ (Poncet et al., 1995b). Here we report evidence that cry $11 A$ is transcribed during the transition phase by the RNA polymerase associated with the $\sigma^{\mathrm{H}}$ factor, from a promoter overlapping the $\sigma^{\mathrm{E}}$-dependent promoter. Primer extension and expression analysis in a spo0 A mutant strain of $B$. thuringiensis suggests that the early transcription of the cry4 genes is also $\sigma^{\mathrm{H}}$-dependent. Our results partially confirm those obtained by Yoshisue et al. (1995), who showed that the cry $4 A$ promoter region is recognized by the $\sigma^{\mathrm{H}}-\mathrm{RNA}$ polymerase during the transition phase. In contrast, no $c r y 4 B$ mRNA was detected by these authors during the late-exponential growth stage (Yoshisue et al., 1994, 1995).

Primer extension analysis also indicates that $c r y 4 \mathrm{~A}$ and cry $11 \mathrm{~A}$ expression is turned off on entry into sporulation in B. thuringiensis. Deletion analysis of the cry11A promoter region implicates the regulatory protein Spo0A in the negative regulation of the $c r y 11 \mathrm{~A}$ operon, probably through interaction with a ' $0 \mathrm{~A}$ ' box. Nevertheless, it seems that this box has no essential role in Cry11A synthesis; also, we cannot exclude the possibility that other regulatory factors are involved in the accumulation of Cry11A inclusions in B. thuringiensis. Our data suggest that the $c r y 4 A, c r y 4 B$ and $c r y 11 A$ genes are all subject to the same early transcriptional regulation, involving a dual regulation system: their promoters are controlled by the $\sigma^{\mathrm{H}}-\mathrm{RNA}$ polymerase during the transition phase and repressed on entry into the sporulation process by interaction of Spo0A with its DNA target. These genes are transcriptionally active in mid-sporulation, due to the $\sigma^{\mathrm{E}}-\mathrm{RNA}$ polymerase. Yoshisue et al. (1995) showed that in B. subtilis cry $4 A$, but not $c r y 4 B$, is transcribed by the $\sigma^{\mathrm{H}}-\mathrm{RNA}$ polymerase. However, they did not observe $c r y 4 A$ repression on entry into sporulation. This difference may be due to different regulation in B. subtilis and in B. thuringiensis and/or to poor cell synchronization. In addition, we detected $c r y 4 B$ mRNA by primer extension experiments using total RNA extracted from a spoOA strain [407$0 \mathrm{~A}$ (pHT692), see Results], in which the cry4B transcriptional activity was threefold higher than in a wildtype background.

The temporal pattern of expression of the cry4-type genes and the cry1A $a$ gene is different, although they 
both harbour $\sigma^{\mathrm{E}}$-dependent promoters (Bravo et al., 1996). $\beta$-Galactosidase synthesis mediated by a transcriptional $c r y 1 A a^{\prime}-l a c Z$ fusion in $B$. thuringiensis cells grown in HCT medium is induced $2 \mathrm{~h}$ after the entry to sporulation, whereas we showed in the present study that the transcription mediated by the cry $4 A, c r y 4 B$ and cry $11 \mathrm{~A}$ sigma-dependent promoters started at $t_{4}-t_{5}$. Moreover, we confirmed that in HCT medium a spoIID'-lacZ fusion, harbouring a $\sigma^{\mathrm{E}}$-dependent promoter, is induced at $t_{2}$ in $B$. thuringiensis (data not shown). These results showed that under our experimental conditions (i) $\sigma^{\mathrm{E}}$ is present - and active $-2 \mathrm{~h}$ after the onset of sporulation, and (ii) the $\sigma^{\mathrm{E}}$-dependent induction of the cry 4 and cry $11 A$ genes is delayed in B. thuringiensis. In B. subtilis, Spo0A is detected within the sporulating cell at least $4 \mathrm{~h}$ after the beginning of sporulation (Baldus et al., 1994). Moreover, as shown in Fig. 5 , the $c r y 11 A^{\prime}$-lac $Z$ fusion is induced at $t_{5}$, whereas after the deletion of the putative ' $O A$ ' ' box, the cry $11 A \triangle O A^{\prime}-$ lac $Z$ is induced at $t_{3}$. It is therefore tempting to suggest that interaction of the Spo0A regulatory protein with its DNA target is responsible for the delay of the $\sigma^{\mathrm{E}}$-dependent transcription of the $c r y$ genes in B. thuringiensis.

Transcription of the $c r y 4$ and cry $11 A$ genes on entry into sporulation may contribute to invasion of insect larvae following spore-crystal ingestion. However, it appears from recent studies that the regulation of toxin genes in $B$. thuringiensis is more complex than previously believed (for a review, see Agaisse \& Lereclus, 1995; Baum \& Malvar, 1995). Spo0A repression may provide a stringent control of cry gene expression from $B$. thuringiensis subsp. israelensis and avoid the titration of regulatory elements at the beginning of the sporulation process. During the transition phase, expression from the $c r y 4 A$ promoter is higher than that from the $c r y 4 B$ or cry $11 \mathrm{~A}$ promoters. Unlike Cry4B and Cry11A, Cry4A does not crystallize when produced alone in a crystalminus strain of B. thuringiensis (Delécluse et al., 1993). Early transcriptional regulation of $c r y$ gene expression is therefore not sufficient to explain the accumulation of the toxins as parasporal inclusions in the mother-cell compartment. Further work is needed to determine the role of sporulation-specific regulators on cry gene expression.

\section{ACKNOWLEDGEMENTS}

We are grateful to Alex Edelman for revising the English manuscript. This work was supported by grants from the Institut Pasteur, the Centre National de la Recherche Scientifique and AgrEvo. S. Poncet was supported by a grant from Université Paris 7 and E. Dervyn by a grant from the Institut National de la Recherche Agronomique.

\section{REFERENCES}

Adams, L. F., Brown, K. L. \& Whiteley, H. R. (1991). Molecular cloning and characterization of two genes encoding sigma factors that direct transcription from a Bacillus thuringiensis crystal protein gene promoter. J Bacteriol 173, 3846-3854.

Agaisse, H. \& Lereclus, D. (1994). Expression of the cryIllA toxin gene of Bacillus thuringiensis is not dependent on sporulationspecific sigma factor and is increased in a spoOA mutant of B. subtilis. J Bacteriol 6, 4734-4741.

Agaisse, H. \& Lereclus, D. (1995). How does Bacillus thuringiensis produce so much insecticidal crystal protein? J Bacteriol 177, 6027-6032.

Baldus, J. M., Green, B. D., Youngman, P. \& Moran, C. P., Jr (1994). Phosphorylation of Bacillus subtilis transcription factor Spo0A stimulates transcription from the spoIIG promoter by enhancing binding to weak $0 A$ boxes. J Bacteriol 176, 296-306.

Baldus, J. M., Buckner, C. M. \& Moran, C. P., Jr (1995). Evidence that the transcriptional activator Spo0A interacts with two sigma factors in Bacillus subtilis. Mol Microbiol 17, 281-290.

Baum, J. A. \& Malvar, T. (1995). Regulation of insecticidal crystal protein production in Bacillus thuringiensis. Mol Microbiol 18, 1-12.

Birnboim, H. C. \& Doly, J. (1979). A rapid alkaline extraction procedure for screening recombinant plasmid DNA. Nucleic Acids Res 7, 1513-1523.

Bravo, A., Agaisse, H., Salamitou, S. \& Lereclus, D. (1996). Analysis of $c r y I A a$ expression in sigE and sigK mutants of Bacillus thuringiensis. Mol Gen Genet 250, 734-741.

Brown, K. L. \& Whiteley, H. R. (1988). Isolation of a Bacillus thuringiensis RNA polymerase capable of transcribing crystal protein genes. Proc Natl Acad Sci USA 85, 4166-4170.

Brown, K. L. \& Whiteley, H. R. (1990). Isolation of the second Bacillus thuringiensis RNA polymerase that transcribes from a crystal protein gene promoter. J Bacteriol 172, 6682-6688.

Calogero, S., Gardan, R., Glaser, P., Schweizer, J., Rapoport, G. \& Débarbouillé, M. (1994). RocR, a novel regulatory protein controlling arginine utilization in Bacillus subtilis, belongs to the $\mathrm{NtrC} / \mathrm{NifA}$ family of transcriptional activators. J. Bacteriol 176, 1234-1241.

Delécluse, A., Poncet, S., Klier, A. \& Rapoport, G. (1993). Expression of cryIVA and cryIVB genes, independently or in combination, in a crystal minus strain of Bacillus thuringiensis subsp. israelensis. Appl Environ Microbiol 59, 3922-3927.

Dervyn, E., Poncet, S., Klier, A. \& Rapoport, G. (1995). Transcriptional regulation of Bacillus thuringiensis subsp. israelensis cryIVD gene operon. J Bacteriol 177, 2283-2291.

Donovan, W. P., Dankocsik, C. \& Gilbert, M. P. (1988). Molecular characterization of a gene encoding a 72-kilodalton mosquitotoxic crystal protein from Bacillus thuringiensis subsp. israelensis. J Bacteriol 170, 4732-4738.

Errington, J. (1993). Bacillus subtilis sporulation: regulation of gene expression and control of morphogenesis. Microbiol Rev 57, $1-33$.

Glatron, M. F. \& Rapoport, G. (1972). Biosynthesis of the parasporal inclusion of Bacillus thuringiensis: half-life of its corresponding messenger RNA. Biochimie 54, 1291-1301.

Haldenwang, W. G. (1995). The sigma factors of Bacillus subtilis. Microbiol Rev 59, 1-30.

Lecadet, M.-M., Blondel, M.-O. \& Ribier, J. (1980). Generalized transduction in Bacillus thuringiensis var. berliner 1715 using bacteriophage CP54Ber. J Gen Microbiol 121, 203-212.

Lereclus, D., Arantes, O., Chaufaux, J. \& Lecadet, M.-M. (1989). Transformation and expression of a cloned $\delta$-endotoxin gene in Bacillus thuringiensis. FEMS Microbiol Lett 60, 211-218. 
Lereclus, D., Agaisse, H., Gominet, M. \& Chaufaux, J. (1994). Overproduction of encapsulated insecticidal crystal proteins in a Bacillus thuringiensis spo0A mutant. Bio/Technology 13, 67-71.

Malvar, T. \& Baum, J. A. (1994). Tn5401 disruption of the spoOF gene, identified by direct chromosomal sequencing, results in CryIIIA overproduction in Bacillus thuringiensis. J Bacteriol 176, $4750-4753$.

Miller, J. H. (1972). Experiments in Molecular Genetics. Cold Spring Harbor, NY: Cold Spring Harbor Laboratory.

Msadek, T., Kunst, F., Henner, D., Klier, A., Rapoport, G. \& Dedonder, R. (1990). Signal transduction pathway controlling synthesis of a class of degradative enzymes in Bacillus subtilis: expression of the regulatory gene and analysis of mutations in degS and degU. J Bacteriol 172, 824-834.

Perego, M., Spiegelman, G. B. \& Hoch, J. A. (1988). Structure of the gene for the transition state regulator, $a b r B$ : regulator synthesis is controlled by the spoOA sporulation gene in Bacillus subtilis. Mol Microbiol 2, 689-699.

Poncet, S., Delécluse, A., Klier, A. \& Rapoport, G. (1995a). Evaluation of synergistic interactions between the CryIVA, CryIVB and CryIVD toxic components of Bacillus thuringiensis subsp. israelensis crystals. J Invertebr Pathol 66, 131-135.

Poncet, S., Dervyn, E., Klier, A. \& Rapoport, G. (1995b). Regulation of the cryIVD operon in Bacillus thuringiensis subsp. israelensis. In 8th International Conference on Bacilli (Abstracts), p. 58, Stanford, CA, USA.

Porter, A. G., Davidson, E. W. \& Liu, J.-W. (1993). Mosquitocidal toxins of Bacilli and their genetic manipulation for effective biological control of mosquitoes. Microbiol Rev 57, 838-861.

Sanger, F., Nicklen, S. \& Coulson, A. R. (1977). DNA sequencing with chain-terminating inhibitors. Proc Natl Acad Sci USA 74, 5463-5467.

Strauch, M., Webb, V., Spiegelman, G. \& Hoch, J. A. (1990). The Spo0A protein of Bacillus subtilis is a repressor of the $a b r B$ gene. Proc Natl Acad Sci USA 87, 1801-1805.
Waalwijk, C., Dullemans, A. M., vanWorkum, M. E. S. \& Visser, B. (1985). Molecular cloning and the nucleotide sequence of the $M_{r}$ 28000 crystal protein gene of Bacillus thuringiensis subsp. israelensis. Nucleic Acids Res 13, 8207-8217.

Ward, E.S. \& Ellar, D. J. (1986). Bacillus thuringiensis var. israelensis $\delta$-endotoxin. Nucleotide sequence and characterization of the transcripts in Bacillus thuringiensis and Escherichia coli. J Mol Biol 191, 1-11.

Weinrauch, Y., Msadek, T., Kunst, F. \& Dubnau, D. (1991). Sequence and properties of $\operatorname{com} Q$, a new competence regulatory gene of Bacillus subtilis. J Bacteriol 173, 5685-5693.

Weir, J., Dubnau, E., Ramakrishna, N. \& Smith, I. (1984). Bacillus subtilis spoOH gene. J Bacteriol 157, 405-412.

Weir, J., Predich, M., Dubnau, E., Nair, G. \& Smith, I. (1991). Regulation of $s p o O H$, a gene coding for the Bacillus subtilis $\sigma^{\mathrm{H}}$ factor. J Bacteriol 173, 521-529.

Wong, H. C., Schnepf, H. E. \& Whiteley, H. R. (1983). Transcriptional and translational start sites for the Bacillus thuringiensis crystal protein gene. J Biol Chem 258, 1960-1967.

Yoshisue, H., Fukada, T., Yoshida, K.-I., Sen, K., Kurosawa, S.-I., Sakai, H. \& Komano, T. (1993). Transcriptional regulation of Bacillus thuringiensis subsp. israelensis mosquito larvicidal crystal protein gene cryIVA. J Bacteriol 175, 2750-2753.

Yoshisue, H., Nishimoto, T., Sakai, H. \& Komano, T. (1994). Identification of a promoter for the crystal protein-encoding gene cryIVB from Bacillus thuringiensis subsp. israelensis. Gene 137, 247-251.

Yoshisue, H., Ihara, K., Nishimoto, T., Sakai, H. \& Komano, T. (1995). Expression of the genes for insecticidal crystal proteins in Bacillus thuringiensis: cryIVA, not cryIVB, is transcribed by RNA polymerase containing $\sigma^{\mathrm{H}}$ and that containing $\sigma^{\mathrm{E}}$. FEMS Microbiol Lett 127, 65-72.

Received 2 April 1997; accepted 7 April 1997. 